\title{
The Effects of Growth Performance and Organosomatic Indices of Atlantic Salmon Juvenile by Using Different Carbohydrate-to-Lipid Ratios in Feeds
}

\author{
Jinghui Li', Lin Ma², Zhenyan Cheng1, Dongqing Bai' ${ }^{1}$ Xiuting Qiao' ${ }^{1}$, Jinhui Sun ${ }^{*}$ \\ ${ }^{1}$ Tianjin Key Lab of Aqua-Ecology and Aquaculture, College of Fisheries, Tianjin Agricultural University, \\ Tianjin, China \\ ${ }^{2}$ Tianjin Fishery Research Institute, Tianjin, China \\ Email: LJH11251110@163.com, linma10@foxmail.com, chengzhenyan2005@126.com, \\ baidongqing@tjau.edu.cn, qxt65@sohu.com, "jhsun1008@163.com
}

Received 20 November 2015; accepted 10 December 2015; published 17 December 2015

\section{Abstract}

The effect of different carbohydrate-to-lipid ratios in feeds on the growth performance and organosomatic indices of Atlantic salmon, Salmon salar, was determined in this experiment. Four isoenergetic feeds were manufactured with increasing carbohydrate level $(18 \%, 21 \%, 14 \%, 26 \%)$. Lipid level was decreasing from $14 \%$ to $11 \%$ for each diet for energetic balance. Fish were reared in triplicate tanks for each diet treatment for 49 days. The diet which contained $26 \%$ carbohydrate and $11 \%$ lipid provided the highest specific growth rate (SGR $=0.66 \% \pm 0.04 \%$ per day) to the fish. However, the feed efficiency (FER) ranked from 0.71 to 0.91 had no significant differences between diets. Similarly, the values of condition index (K), relative gut length (RGL) and hepatosomatic index (HSI) had no significant differences between groups. The relationship between liver and carcass weight showed that with the increasing of fish carcass weight, the liver weight increased. According to this experiment, it suggests that based on an optimum level of carbohydrate in diet, the juvenile salmon has a better growth fed by a diet with a higher carbohydrate-to-lipid ratio.

\section{Keywords}

Atlantic Salmon, Carbohydrate, Lipid, Growth Performance, Organosomatic Indices

\section{Introduction}

Carbohydrate is regarded as one of the most important energetic resources besides protein and lipid, but the utilization of it by fish is still thought obscure [1]. Based on relevant researches, they reveal that most fish species

${ }^{*}$ Corresponding author. 
suffered from reducing growth rates when they were fed with carbohydrate-free diet. Wilson [1] found that higher value of carbohydrate could be used by warmwater fish than marine or coldwater fish. Some study indicated that rainbow trout had a better growth when fed by higher level of carbohydrate in diet [2]. Similarly result was found by Bergot [3], he revealed that trout could achieve the highest growth rate by feeding a high value carbohydrate diet. However, several studies showed there were not many effects on growth performance and feed efficiency by feeding some carnivorous fish with an increasing dietary carbohydrate [4]-[6]. This report aims to determine the effects of growth performance and organosomatic indices of Atlantic salmon juvenile by using the different carbohydrate-to-lipid ratios in diets.

\section{Methods and Materials}

\subsection{Diet Composition}

Four iso-energetic diets $(1.5 \mathrm{~mm}$ in diameter) with different carbohydrate-to-lipid ratios (Table 1) were produced in Aquaculture Centre, University of Tasmania. The dry ingredients were put into a container then mixed using a 20-L Brice mixer. After 20 minutes mixing, fish oil was added into the mixture and continued to mix another 20 minutes. Then, added approximately $30 \%$ water into the mixture until it formed as a crumby dough. The diet pellet was made by Italpast Pastamaker with a pellet cutter. Scattered the pellet onto a board with screen and dried it at $90^{\circ} \mathrm{C}$ in 24 hours, lastly, stored the feed in the freezer at $-20^{\circ} \mathrm{C}$ until use.

\subsection{Growth Trial}

Approximately 180 Atlantic salmon (Salmo salar) juvenile (11.31 $\pm 0.64 \mathrm{~g})$ were used as the experimental fish fed by four different diets during 1st August to 18th September, 2013 in aquaculture centre. The 12 experimental

Table 1. The formulation and chemical composition of the experimental diets $\left(\mathrm{g} \cdot \mathrm{kg}^{-1}\right)$.

\begin{tabular}{|c|c|c|c|c|}
\hline Diet & 18CHO:14L ${ }^{*}$ & 21CHO:13L & 24CHO:12L & 26CHO:11L \\
\hline \multicolumn{5}{|c|}{ Ingredient composition $\left(\mathrm{g} \cdot \mathrm{kg}^{-1}\right)$} \\
\hline Fish meal & 511 & 511 & 511 & 511 \\
\hline Wheat gluten & 100 & 100 & 100 & 100 \\
\hline Fish oil & 108 & 95 & 81 & 72 \\
\hline Pregel maize starch (bo11c) & 180 & 210 & 240 & 260 \\
\hline Vitamins & 15 & 15 & 15 & 15 \\
\hline Minerals & 15 & 15 & 15 & 15 \\
\hline Stay C & 15 & 15 & 15 & 15 \\
\hline Choline chloride & 1 & 1 & 1 & 1 \\
\hline Monobasic calcium phosphate & 10 & 10 & 10 & 10 \\
\hline Ytterbium oxide & 1 & 1 & 1 & 1 \\
\hline$\alpha$-cellulose & 44 & 27 & 11 & 0 \\
\hline \multicolumn{5}{|c|}{ Chemical composition (Dry matter basic) } \\
\hline Dry matter & 907.1 & 903.2 & 907.7 & 906.3 \\
\hline Crude protein & 440 & 440 & 440 & 440 \\
\hline Crude lipid & 167.9 & 155.3 & 140.2 & 131.1 \\
\hline Ash & 109.4 & 106.7 & 110.1 & 107.4 \\
\hline $\mathrm{NFE}$ & 191.1 & 204 & 214.2 & 224.2 \\
\hline Gross energy $\left(\mathrm{MJ} \cdot \mathrm{kg}^{-1}\right)$ & 22 & 22 & 22 & 22 \\
\hline CHO:L & 1.07 & 1.35 & 1.71 & 1.98 \\
\hline
\end{tabular}


tanks were randomly chosen for triplicate for each diet treatment (3 tanks for each diet, 15 fish each tank). Before the experiment, fish were held in a $4000 \mathrm{~L}$ rathbun tank and fed a commercial salmon feed (Skretting Australia). After the fish got anesthesia by experiencing an anesthetic bath in the tank $(150 \mathrm{~L}$ with $13 \mathrm{mg} / \mathrm{L}$ clove oil), they were individually measured for the fork length and the whole weight by using a recreational marine scalefish ruler and a digital balance. Then the fish would be fed to $90 \%$ of satiation at $1.5 \%$ body weight per day over 7 weeks, 5 days a week. The photoperiod was set up at 12:12 in a day. The feeding behaviour, diet consumption and water quality indices were detected and recorded daily.

After the 49-days experiment, the whole weight and fork length of individual fish were measured again. Two fish of each tank were selected for organosomatic indices calculation. The test items included the fish whole weight, fork length, digestive tract length, intestine length, liver weight (without gall bladder), pylorus weight (with fat), stomach weight (without fat), intestine weight (without fat) and carcass weight.

\subsection{Calculation and Formula}

According to Glencross, et al. [7] and Kaushik [8], the growth performance and the efficiency of food of this experiment were calculated as specific growth rate (SGR) and feed conversion ratio (FCR).

$$
\begin{aligned}
\operatorname{SGR}(\% / \text { day }) & =[100 \times(\ln (\text { final weight })-\ln (\text { initial weight })] / \text { days fed } \\
\text { FCR } & =\text { feed consumed }(\mathrm{g}) / \text { weight gained }(\mathrm{g})
\end{aligned}
$$

The condition index (K), organ somatic indices (OSI) and relative gut length (RGL) were calculated based on the following formulas:

$$
\begin{gathered}
\mathrm{K}(\%)=[\text { wet weight }(\mathrm{g}) / \text { fork length } 3(\mathrm{~cm})] \times 100 \\
\text { OSI }(\%)=[\text { organ weight }(\mathrm{g}) / \text { wet weight }(\mathrm{g})] \times 100 \\
\mathrm{RGL}=\text { digestive tract length }(\mathrm{cm}) / \text { fork length }(\mathrm{cm}) \\
\text { Hepatosomatic index }(\text { HSI, } \%)=[\text { liver weight }(\mathrm{g}) / \text { body weight }(\mathrm{g})] \times 100
\end{gathered}
$$

\subsection{Data Analyses}

The data of this experiment was analyzed by using Excel and one-way analysis of variance (ANOVA). A Tukey test was used if there was a significant difference between treatment means. The level of significance for all tests was chosen at $\mathrm{P} \leq 0.05$. The results were given as mean \pm standard error of the mean (S.E.M.).

\section{Results}

\subsection{Growth and Feed Efficiency}

There was a significant difference in mean specific growth rate (SGR \% per day) of groups fed by different carbohydrate levels $(\mathrm{F}=5.126, \mathrm{df}=3,8, \mathrm{P}=0.029)$. The highest SGR occurred in the salmon fed by diet with 26CHO:11L $(0.66 \% \pm 0.04 \%)$ which was approximately $14 \%$ higher than fed by diet with 21CHO:12L (SGR $0.45 \% \pm 0.04 \%$ ) (Figure 1).

The efficiency of food (FER) was not significant different $(\mathrm{F}=3.256$; $\mathrm{df}=3,8 ; \mathrm{P}=0.081$ ), ranged from 0.76 to 0.91 (Table 2).

\subsection{Organosomatic Indices}

Table 3 shows the condition index (K) and relative gut length (RGL) between groups were not significantly different. Values ranging from $1.068 \pm 0.024 \%$ to $1.153 \% \pm 0.086 \%$ for $\mathrm{K}$ and from $0.79 \pm 0.03$ to $0.89 \pm 0.07$ for RGL. However, the hepatosomatic indices (HSI) showed a significant difference between each group $(\mathrm{F}=4.616$, $\mathrm{df}=3$, 20; $\mathrm{P}=0.013$ ). The highest HSI value (24CHO:12L, $2.71 \% \pm 0.23 \%$ ) was $15 \%$ higher than the lowest one (18CHO:14L, $1.76 \% \pm 0.24 \%$ ) approximately (Table 3). 


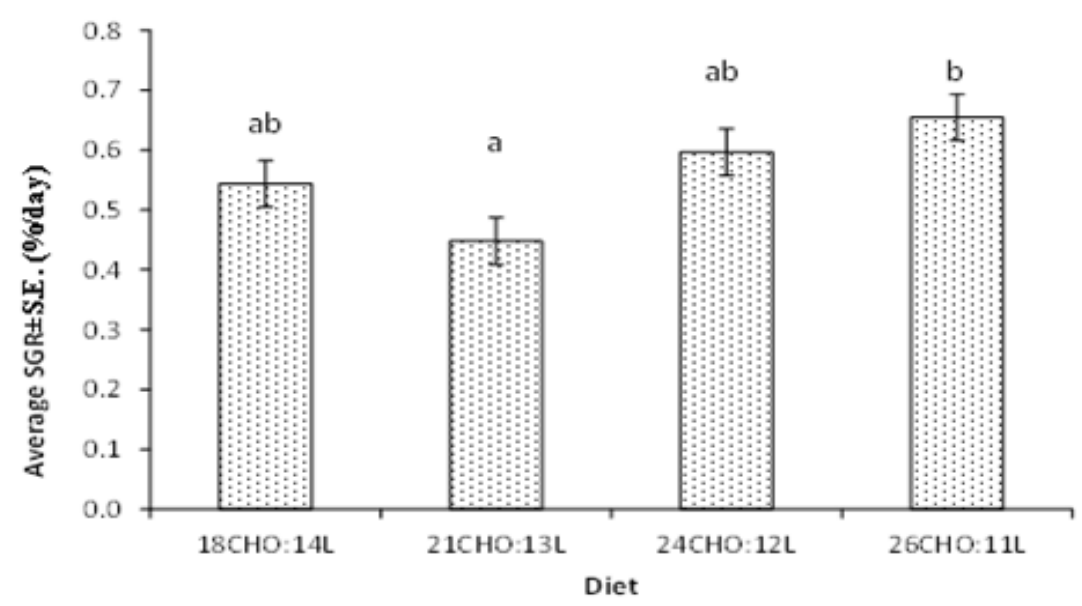

Figure 1. Mean SGR (\%/day) of the test salmon fed by different diets over 49 days. Values are mean \pm SE. Means with different letters are significantly different from one another.

Table 2. Feed efficiency (FER) (mean \pm S.E.) of salmon, Salmon salar fed by four different diets over 7 weeks.

\begin{tabular}{cccccc}
\hline & 18CHO:14L & 21CHO:13L & 24CHO:12L & 26CHO:11L & S \\
\hline Initial weight (g) & $11.89 \pm 0.40$ & $11.02 \pm 0.29$ & $11.08 \pm 0.43$ & $11.27 \pm 0.40$ & NS \\
Final weight (g) & $15.51 \pm 0.92$ & $13.71 \pm 0.97$ & $14.75 \pm 0.93$ & $15.53 \pm 0.91$ & NS \\
FRE & $0.76 \pm 0.08$ & $0.71 \pm 0.03$ & $0.91 \pm 0.05$ & $0.89 \pm 0.04$ & NS \\
\hline
\end{tabular}

Table 3. Condition index (K), hepatosomatic index (HSI) and relative gut length (RGL) (Mean \pm S.E.) in salmon fed by four different diets over 7 weeks.

\begin{tabular}{cccccc}
\hline & 18CHO:14L & 21CHO:13L & 24CHO:12L & 26CHO:11L & S \\
\hline K (\%) & $1.068 \pm 0.024$ & $1.220 \pm 0.092$ & $1.153 \pm 0.086$ & $1.146 \pm 0.036$ & NS \\
RGL & $0.79 \pm 0.03$ & $0.83 \pm 0.04$ & $0.89 \pm 0.07$ & $0.85 \pm 0.04$ & NS \\
HIS (\%) & $1.76 \pm 0.24^{\mathrm{a}}$ & $2.47 \pm 0.11^{\mathrm{ab}}$ & $2.71 \pm 0.23^{\mathrm{b}}$ & $2.36 \pm 0.35^{\mathrm{ab}}$ & $\mathrm{S}$ \\
\hline
\end{tabular}

\subsection{The Relationship between Liver Weight and Carcass Weight}

Figure 2 shows the relationship between the liver weight and carcass weight of tested fish. It can be observed that the liver weight increases with the increasing of carcass weight in each diet treatment.

\section{Discussion}

It was shown in this experiment that salmon can get the highest SGR fed by the diet with the highest carbohydrate-to-lipid ratio (26CHO:11L). It showed the similar results with previous researches worked by GrisdaleHelland \& Helland [9], Krogdahl et al. [2] and Hemre et al. [10].

There are two explanations for this result. Firstly, fish catabolizes diet for energy start from carbohydrate to lipid and protein, if appropriate level of carbohydrate is not provided, lipid even protein will be catabolized for energy, this must influence the growth of the fish [1]. If the diet has a high level of carbohydrate, the extra carbohydrate can spare protein to store as growth [11] [12]. Secondly, increasing level of carbohydrate in diet improves the protein efficiency [13]. This may due to carbohydrate can stimulate the activity of certain enzymes to bring fish a better absorption of protein [14].

However, several studies showed there were not many effect on growth performance and feed efficiency by feeding some fish with an increasing dietary carbohydrate [4]-[6]. This may be caused by different source of carbohydrate that can significantly affect the digestibility of fish [14] and the level of digestible carbohydrate varies among fish species [1]. 


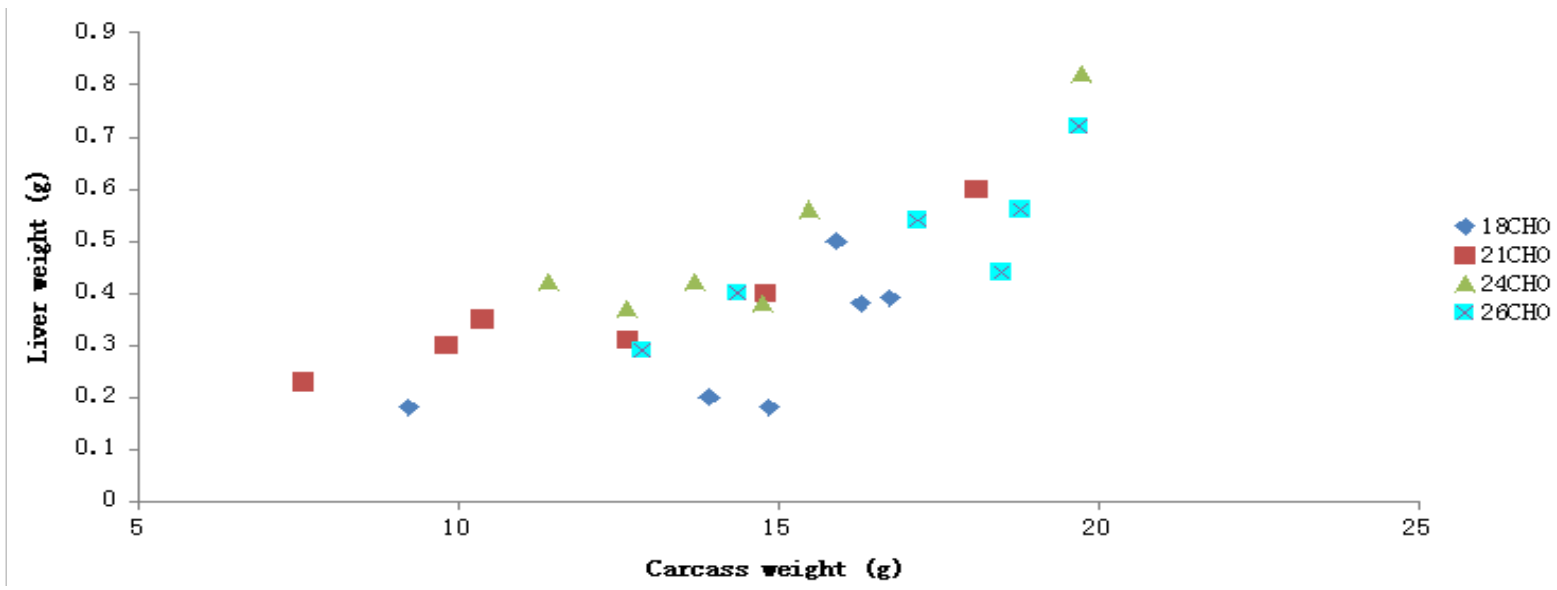

Figure 2. The relationship between liver weight and carcass weight of the tested salmon in each diet treatment.

The lowest hepatosomatic index (HSI) occurred in the lowest level of carbohydrate diet (18CHO:14L), but the highest HSI did not occur in the diet with the highest carbohydrate-lipid ratio (26CHO:14L). However, there was a positive relationship between liver weight and carcass weight in this experiment. Therefore, even though the viscera and muscle fat content of fish can be increased by feeding the diet which contains increased level of carbohydrate [5], the liver size seems to be little influenced by dietary carbohydrate level in Atlantic salmon [15].

\section{Conclusion}

In this experiment, the diet (26CHO:14L) provided the highest SGR to the fish. It showed that based on an optimum level of carbohydrate in diet, the juvenile salmon had a better growth fed by a diet with a higher carbohydrate-to-lipid ratio. However, the FER had no significant different between diets. Similarly, the values of K, RGL and HSI had no significant differences between groups. The relationship between liver and carcass weight showed that with the increasing of fish carcass weight, the liver weight increased.

\section{References}

[1] Wilson, R.P. (1994) Utilization of Dietary Carbohydrate by Fish. Aquaculture, 124, 67-80. http://dx.doi.org/10.1016/0044-8486(94)90363-8

[2] Krogdahl, Å., Sundby, A. and Olli, J. J. (2004) Atlantic Salmon (Salmo salar) and Rainbow Trout (Oncorhynchus mykiss) Digest and Metabolize Nutrients Differently. Effects of Water Salinity and Dietary Starch Level. Aquaculture, 229, 335-360. http://dx.doi.org/10.1016/S0044-8486(03)00396-X

[3] Bergot, F. (1979) Carbohydrate in Rainbow Trout Diets: Effects of the Level and Source of Carbohydrate and the Number of Meals on Growth and Body Composition. Aquaculture, 18, 157-167. http://dx.doi.org/10.1016/0044-8486(79)90028-0

[4] Moreira, I. S., Peres, H., Couto, A., Enes, P. and Oliva-Teles, A.(2008) Temperature and Dietary Carbohydrate Level Effects on Performance and Metabolic Utilisation of Diets in European Sea Bass (Dicentrarchus labrax) Juveniles. Aquaculture, 274, 153-160. http://dx.doi.org/10.1016/j.aquaculture.2007.11.016

[5] Dias, J., Rueda-Jasso, R., Panserat, S., da Conceição, L.E.C., Gomes, E.F. and Dinis, M.T. (2004) Effect of Dietary Carbohydrate-to-Lipid Ratios on Growth, Lipid Deposition and Metabolic Hepatic Enzymes in Juvenile Senegalese Sole (Soleasenegalensis Kaup). Aquacult. Res., 35, 1122-1130. http://dx.doi.org/10.1111/j.1365-2109.2004.01135.x

[6] Guerreiro, I., Peres, H., Castro, C., Pérez-Jiménez, A., Castro-Cunha, M. and Oliva-Teles, A. (2012) Water Temperature Does Not Affect Protein Sparing by Dietary Carbohydrate in Senegalese Sole (Solea senegalensis) Juveniles. Aquacult. Res., 1-10.

[7] Glencross, B.D., Booth, M. and Allan, G.L. (2007) A Feed Is Only as Good as Its Ingredients—A Review of Ingredient Evaluation Strategies for Aquaculture Feeds. Aquaculture Nutrition, 13. http://dx.doi.org/10.1111/j.1365-2095.2007.00450.x

[8] Kaushik, S.J. (1998) Nutritional Bioenergetics and Estimation of Waste Production in Non-Salmonids. Aquat. Living 
Resour, 11, 311-318. http://dx.doi.org/10.1016/S0990-7440(98)89003-7

[9] Grisdale-Helland, B. and Helland, S.J. (1997) Replacement of Protein by Fat and Carbohydrate in Diets for Atlantic Salmon (Salmo salar) at the End of the Freshwater Stage. Aquaculture, 152, 167-180. http://dx.doi.org/10.1016/S0044-8486(97)00003-3

[10] Hemre, G.I., Sandnes, K., Lie, Ø., Torrissen, O. and Waagbø, R. (1995) Carbohydrate Nutrition in Atlantic Salmon, Salmo salar L.: Growth and Feed Utilization. Aquacult. Res. 26, 149-154. http://dx.doi.org/10.1111/j.1365-2109.1995.tb00896.x

[11] Oliva-Teles, A. (2012) Nutrition and Health of Aquaculture Fish. J. Fish Dis, 35, 83-108. http://dx.doi.org/10.1111/j.1365-2761.2011.01333.x

[12] Stone, D.A.J. (2003) Dietary Carbohydrate Utilization by Fish. Reviews in Fisheries Science, 11, 337-369. http://dx.doi.org/10.1080/10641260390260884

[13] Amin, M.N. (2013) Protein and Energy Nutrition of Brook Trout, Salvelinus fontinalis (Mitchill, 1814). Thesis, University of Tasmania, Australia. http://eprints.utas.edu.au/17062/1/Whole-Amin-_Thesis_-_July_2013.pdf

[14] Wee, K.L. (1992) An Overview of Fish Digestive Physiology and the Relevance to the Formulation of Artificial Fish Feeds. Aquaculture Nutrition Workshop, 17-24.

[15] Hemre, G.I., Mommsen, T.P. and Krogdahl, Å. (2002) Carbohydrates in Fish Nutrition: Effects on Growth, Glucose Metabolism and Hepatic Enzymes. Aquacult. Nutr, 8, 175-194. http://dx.doi.org/10.1046/j.1365-2095.2002.00200.x 